\title{
Hubungan Profitabilitas terhadap Pembayaran Zakat Bank Umum Syariah di Indonesia
}

\author{
Dwi Santosa Pambudi \\ Fakultas Agama Islam, Program Studi Perbankan Syariah, Universitas Ahmad Dahlan, Yogyakarta, Indonesia \\ Email: dwi.pambudi@pbs.uad.ac.id \\ Submitted: 08/11/2021; Accepted: 26/11/2021; Published: 30/11/2021
}

\begin{abstract}
Abstrak-Fungsi sosial bank syariah ditunjukkan dengan kepatuhan membayar zakat perusahaan. Namun demikian, jumlah pembayaran zakat perusahaan oleh Bank syariah sangat dipengaruhi oleh tingkat profitabilitasnya. Karenanya, tujuan studi ini untuk menginvestigasi hubungan profitabilitas terhadap pembayaran zakat bank syariah. Populasi penelitian ini meliputi seluruh Bank Umum Syariah yang berjumlah 14 Unit. Tekhnik pengambilan sampel menggunakan metode purposive sampling. Variabel profitabilitas dilihat dari rasio ROA dan pembayaran zakat dilihat dari zakat perusahaan dengan analisis regresi linier berganda. Temuan penelitian menunjukkan bahwa tingkat profitabilitas yang diwakili ROA mempunyai hubungan yang negatif positif terhadap zakat yang dikeluarkan oleh bank umum syariah.
\end{abstract}

Kata Kunci: Bank Umum Syariah; ROA; Profitabilitas; Zakat Perusahaan

\begin{abstract}
The social function of Islamic banks is in accordance with the company's compliance with paying zakat. However, the amount of corporate zakat payments by Islamic banks is strongly influenced by the level of profitability. Therefore, the purpose of this study is to investigate the relationship between profitability and zakat payment for Islamic banks. The population of this study includes all Islamic Commercial Banks totaling 14 units. The sampling technique used purposive sampling method. Profitability variables are seen from the ratio of ROA and zakat payments are seen from company zakat with multiple linear regression analysis. The research findings show that the level of profitability represented by ROA has a negative relationship to the zakat paid by Islamic commercial banks.
\end{abstract}

Keywords: Islamic Commercial Bank; ROA; Profitability; Zakat of Company

\section{PENDAHULUAN}

Selain menjalankan peran intermediary, bank syariah juga menjalankan peran sosial berupa pengumpulan zakat, infak, sedekah baik dari nasabah dan pegawai. Salah satu bentuk kepatuhan perusahaan Islam yang menjalankan prinsip-prinsip syariah, bank syariah melakukan pembayaran zakat perusahaan setiap tahunnya (Wahyudi, 2015). Zakat perusahaan berdasarkan hasil keputusan Muktamar Internasional I tentang zakat di Kuwait, bahwa perusahaan wajib mengeluarkan zakat, karena keberadaan perusahaan sebagai wadah usaha menjadi badan hukum dengan tarif sama dengan tarif zakat perdagangan yaitu 2,5\% (Hafidhuddin, 2004).

Sumber pembayaran zakat bank syariah diperoleh dari pendapatan yang diperoleh selama satu periode operasional. Semakin besar pembayaran zakat yang berarti semakin besar pendapatan yang diperoleh bank syariah dan sebaliknya (Putrie \& Achiria, 2019). Berdasarkan hal tersebut, rasio zakat menunjukkan tingkat profitabilitas bank syariah. Profitabilitas merefleksikan kemampuan bank dalam memperoleh keuntungan (Nahar \& Prawoto, 2017) yang mengindikasikan kinerja keuangan.

Selama ini tumpuan profitabilitas bank syariah didapatkan dari penyaluran dana bank syariah dengan pendekatan akad berbasis jual beli, bagi hasil dan sewa yang berbeda karakteristiknya dengan bank konvensional (Nafik, Ryandono, \& Wahyudi, 2018). Pendapatan bank syariah bergantung sekali dengan pendapatan mitra. Artinya, jika pendapatan mitra mengalami penurunan, maka pendapatan bank syariah akan mengalami hal yang sama, dan sebaliknya. Karena itu, bank syariah mempunyai keunikan dalam proses bisnis yang sekaligus menjalankan pembayaran zakat perusahaan.

Selain itu, dalam praktiknya terdapat perbedaan dalam menentukan komponen pembayaran zakat perusahaan. Zakat perusahaan di Indonesia menerapkan komponen aset bersih dengan laba sebelum pajak. Artinya, semakin tinggi aset bersih, menunjukkan rasio zakat tinggi dan sebaliknya (MUHAMMMAD SYA FUDIN, 2016). Selanjutnya, Wahyudi (Wahyudi, 2015) menyebutkan bahwa setiap periode produktivitas aset pada satu tahun haul akan terpisah dengan tahun sebelumnya atau berikutnya. Oleh karena itu, kewajiban zakat perusahaan tidak bisa diestimasi dan dipukul rata untuk besaran tahunnya. Hal ini mengingat pendapatan dan biaya-biaya setiap bank syariah berbeda-beda.

Studi tentang hubungan profitabilitas bank syariah terhadap pembayaran zakat telah luas dilakukan seperti Sumiyati (Sumiyati, 2019), Krisdiyanti dkk (Imanuddin \& Suryanata, 2019), Afandi (Afandi, 2019), (Rhamadhani, 2016), Firmansyah dan Rusydiana (Firmansyah \& Rusydiana, 2013). Beberapa indikator profitabilitas yaitu ROA dan ROE yang digunakan luas oleh perusahaan dan para peneliti seperti Kumbirai dan Webb (Kumbirai \& Webb, 2010), Siraj dan Pillai (K.K. Siraj and P. Sudarsanan Pillai, 2012) Petersen dan Schoeman (Petersen \& Schoeman, 2008), Tamimi (Al-tamimi, 2010).

Studi lain yang dilakukan Wardani dkk (Wardani, Anita, Putry, \& Lestari, 2020) yang menguji profitabilitas dengan zakat perusahaan dan Islamic Social Reporting (ISR). Ia mengeksplorasi 6 BUS periode 2014-2019 dengan uji Moderated Regression Analysis (MRA). Temuan penelitian ini menunjukkan adanya hubungan profitabilitas terhdapa zakat perusahaan, namun ISR tidak mampu merefleksikan moderasi hubungan tersebut. Nurindahyanti dkk (Nurindahyanti, Tri Kristanti Rahman, 2021) melakukan uji zakat perusahaan, CSR, dan ukuran bank terhadap 
profitabilitas bank umum syariah periode 2015-2019. Regresi berganda dilakukan untuk menguji antar variabel. Temuan penelitian menunjukkan semua variabel mempunyai pengaruh terhadap profitabilitas bank umum syariah.

Selanjutnya, studi Putrie dan Achiria (Putrie \& Achiria, 2019) yang menganalisis dampak profitabilitas terhadap zakat perusahaan pada bank Devisa syariah periode 2012-2016 dengan menggunakan data triwulan. Hasil studi menunjukkan indikator profitabilitas seperti ROA, NPM, OIROI memiliki pengaruh terhadap kemampuan zakat perusahaan dari bank syariah. Berbeda dengan temuan studi-studi sebelumnya, Pattiala (Di \& Syariah, 2018) yang menemukan bahwa ukuran kinerja seperti ROA, NPF, FDR dan BOPO tidak mampu melihat hubungan kinerja terhadap jumlah zakat Bank Syariah Mandiri periode 2011-2018.

Beberapa studi sebelumnya menemukan hubungan positif antara profitabilitas dengan tingkat pembayaran zakat perusahaan, namun terdapat juga studi yang menemukan hasil berbebeda. Karena itu, tujuan penelitian ini akan menguji kembali hubungan profitabilitas dengan pendekatan rasio ROA terhadap pembayaran zakat perusahaan periode 20162019 sehingga temuan penelitian ini dapat melihat trend tahunan dan menggambarkan data terbaru. Sementara urgensi penelitian ini dilakukan untuk menggali kontribusi profitabilitas bank syariah terhadap pembayaran zakat perusahaan, dimana zakat tersebut dapat disalurkan kepada berhak yang menerima dan pada akhirnya dapat mengurangi kesenjangan kemiskinan di masyarakat.

\section{METODE PENELITIAN}

Penelitian ini termasuk jenis kuantitatif dengan pendekatan asosiatif. Profitabilitas diukur dengan rasio ROA dan zakat diperoleh dari pengeluaran zakat perusahaan. Populasi pada studi ini adalah seluruh bank umum syariah. Sedangkan metode pengambilan sampel menggunakan pendekatan purposive sampling. Pendekatan ini luas digunakan oleh para peneliti untuk mendapatkan sampel yang representatif. Jumlah sampel sebanyak 13 Bank Umum Syariah yang telah mempublikasikan pada laporan tahunan periode 2016-2019. Untuk menjawab hipotesis, teknik analisis regresi linier.

\section{HASIL DAN PEMBAHASAN}

Berdasarkan hasil analisis yang telah dilakukan, maka diperoleh hasil hubungan profitabilitas yang diproksi dengan ROA terhadap zakat perbankan syariah diperoleh tingkat signifikansi sebesar sig. $t$ sebesar $0.876(p>0.05)$ dan dan nilai koefisien regresi - 0.004437 maka dapat disimpulkan bahwa ROA (Return on Asset) tidak berpengaruh signifikan terhadap zakat.

Berbeda dengan hasil penelitian-penelitian terdahulu yaitu, pertama Sri Zaitun (2001) tentang pengaruh kinerja terhadap kemampuan zakat pada Bank Muamalat Indonesia (BMI) perode 31 Desember 1993 - 31 Desember 2000 bahwa rasio ROA (return on Asset) berpengaruh positif secara statistik signifikan terhadap zakat. Kedua, Hasil penelitian Khairul Ikhwan (1999) juga berbeda, dimana kinerja keuangan yaitu profitabilitas yang diproksi rasio ROA (return on Asset) , secara parsial berpengaruh positif signifikan terhadap kemampuan zakat pada Lembaga Keuangan Syariah (studi pada Baitul Mal Wat Tamwil (BMT) Binaan PINBUK Jawa Tengah) yang ditunjukkan dengan nilai signifikansi uji t sebesar 0,035 , dimana angka ini berada di bawah level of significance yang digunakan yaitu $5 \%(0,05)$. Ketiga, Ahmad Nurul Muammar (2010) menguji hubungan kinerja keuangan dilihat dari rasio profitabilitas (ROA dan ROE) dengan kemampuan zakat pada bank syariah. Hasil pengujian koefisien determinasi yang dinotasikan Adjusted R Square adalah 0,380 atau $38,00 \%$. Artinya sebesar 38,00\% variasi kemampuan zakat bisa dijelaskan oleh variasi dari variabel independen ROA dan ROE. Sehingga disimpulkan bahwa terdapat hubungan yang signifikan antara kinerja keuangan dilihat dari rasio profitabilitas berupa ROA dan ROE dengan kemampuan zakat pada bank syariah.

ROA (Return on Asset) digunakan untuk mengukur efektivitas perusahaan dalam menghasilkan keuntungan dengan mamanfaatkan aktiva yang dimilikinya. ROA (Return on Asset) merupakan rasio antara laba sesudah pajak terhadap total aset. Semakin besar ROA (Return on Asset) menunjukkan kinerja perusahaan semakin baik, kerena tingkat pengembalian (return) semakin besar. Semakin besar ROA (Return on Asset) suatu bank, semakin besar pula tingkat keuntungan yang dicapai bank, dan semakin baik posisi bank tersebut dari segi penggunaan asset.

Pengaruh negatif yang ditunjukkan oleh ROA (Return on Asset) mengindikasikan bahwa semakin kecil rasio ini mengindikasikan keuntungan atas asset mengalami penurunan, sehingga hal tersebut akan mengurangi kemampuan perbankan syariah menghasilkan pendapatan. Sebaliknya, apabila ROA (Return on Asset) mengalami kenaikan, maka pertumbuhan laba akan mengalami kenaikan. Tidak adanya pengaruh rasio ROA (Return on Asset) terhadap zakat diduga porsi share asset perbankan syariah untuk memperoleh keuntungan dalam bentuk financing masih relative kecil. Artinya sebagian besar ekspansi dana dari dana pihak ketiga (DPK), sedangkan dana dari modal hanya sebagian kecil yang digunakan untuk ekspansi dalam bentuk pembiayaan. Sehingga expected return yang berasal dari asset belum memenuhi ekspektasi terhadap zakat perbankan syariah.

Keberhasilan perbankan syariah sangat bergantung pada perolehan pendapatan, salah satunya melalui share modal bank syariah dalam penyaluran dana kepada pihak ketiga. Namun, bank syariah pada tataran yang lebih luas, keberhasilan usaha juga diukur secara khusus dari keberhasilan menerapkan prinsip-prinsip syariah dan secara umum meningkatkan kemaslahatan umat melalui zakat. Zakat perbankan syariah dapat digunakan seperti program penyaluran dana zakat bagi para mustahik yang membutuhkan. Santunan yang diberikan dapat berupa bantuan pendidikan, kesehatan, sosial, dan kemanusiaan. 


\section{KESIMPULAN}

Hasil temuan penelitian menunjukkan bahwa tidak terdapat hubungan ROA terhadap zakat yang dibayarkan oleh bank umum syariah. Rekomendasi pada penelitian berikutnya agar menambah jumlah variabel, tahun observasi, sampel dengan perbandingan penelitian untuk memperoleh hasil yang komprehensif.

\section{UCAPAN TERIMAKASIH}

Terima kasih disampaikan kepada LPPM Universitas Ahmad Dahlan yang telah memberikan pendanaan penelitian dengan nomor kontrak Nomor: PD-045/SP3/LPPM-UAD/V/2021.

\section{REFERENCES}

Afandi, M. A. (2019). Profitability Variables and Bank Size Effects on Corporate Zakat: Evidence from Indonesian Islamic Banks. Vol. 4(1) 2019 Page 55-66 Profitability, 4(23), 55-66.

Al-tamimi, H. A. H. (2010). Factors Influencing Performance of the UAE Islamic and Conventional National Banks. Global Journal Of Business Research, 4(2), 1-9.

Di, Z., \& Syariah, B. (2018). Pengaruh kinerja keuangan terhadap jumlah zakat di bank syariah mandiri (2011-2018) rambi pattiala, $1-21$.

Firmansyah, I., \& Rusydiana, A. S. (2013). Pengaruh Profitabilitas Terhadap Pengeluaran Di Indonesia Dengan Ukuran Perusahaan. Jurnal Liquidity, 2(2), 110-116.

Hafidhuddin, D. (2004). Zakat dalam Perekonomian Modern. Jakarta: Gema Insani Press.

Imanuddin, B., \& Suryanata, I. P. (2019). Jurnal Manajemen dan Bisnis. Jurnal Manajemen Dan Bisnis, 8(2), 342-353. Retrieved from http://journal.stieindragiri.ac.id/index.php/jmbi\%0

K.K. Siraj and P. Sudarsanan Pillai. (2012). Comparative study on performance of Islamic banks and conventional banks: Evidence from Oman. Journal of Applied Finance \& Banking, 2(3), 123-161.

Kumbirai, M., \& Webb, R. (2010). A financial Ratio Analysis of Commercial Bank Performance in South Africa. African Review of Economics and Finance, 2(1), 30-53.

Muhammmad Syafudin. (2016). Pengaruh Kinerja Keuangan Terhadap Zakat Perbankan Syariah Di Indonesia Dengan Size Bank Sebaga Variabel Moderasi. Thesis UIN Sunan Kalijaga

Nafik, M., Ryandono, H., \& Wahyudi, R. (2018). Manajemen Bank Islam: Pendekatan Syariah dan Praktik. Yogyakarta: UAD Press.

Nahar, F. H., \& Prawoto, N. (2017). Bank'S Profitability in Indonesia: Case Study of Islamic Banks Period 2008-2012. Jurnal Ekonomi \& Studi Pembangunan, 18(2). https://doi.org/10.18196/jesp.18.2.4043

Nurindahyanti, Tri Kristanti Rahman, G. W. M. (2021). Pengaruh Zakat Perbankan, Corporate Social Responsibility (CSR) Dan Ukuran Perusahaan Terhadap Kinerja Bank Umum Syariah (Studi Empiris Pada Bank Umum Syariah di Indonesia yang Terdaftar di OJK Periode 2015-2019). Jurnal Ekonomi: Akuntansi Dan Manajemen, 11(1), 30-41.

Petersen, P. M. A., \& Schoeman, I. (2008). Modeling of Banking Profit via Return-on-Assets and Return-on-Equity. Lecture Notes in Engineering and Computer Science, 2171(1), 828-833.

Putrie, R. D. N., \& Achiria, S. (2019). Pengaruh Rasio Profitabilitas Terhadap Zakat Perusahaan Pada Bank Devisa Syariah. Al-Azhar Journal of Islamic Economics, 1(1), 38-48. https://doi.org/10.37146/ajie.v1i1.12

Rhamadhani, R. F., (2016). Pengaruh Zakat Terhadap Kinerja Perusahaan (Studi Empiris pada Bank Umum Syariah di Indonesia). Hunafa: Jurnal Studia Islamika, 13(2), 345-361.

Sumiyati, A. (2019). Pengaruh Profitabilitas Terhadap Pengeluaran Zakat Dengan Ukuran Perusahaan Sebagai Variabel Moderasi Pada Bank Umum Syariah Di Indonesia. Jurnal Pendidikan Akuntansi \& Keuangan, 5(1), 1-9. https://doi.org/10.17509/jpak.v5i1.15379

Wahyudi, R. (2015). Pengaruh Kinerja Keuangan Terhadap Zakat Perbankan Syariah Di Indonesia. Muqaddimah, 1(2015), 61-84

Wardani, D. K., Anita, N., Putry, C., \& Lestari, R. E. (2020). Pengaruh Profitabilitas Terhadap Zakat Bank Syariah Dengan Islamic Social Reporting (ISR) Sebagai Variabel Moderating Dewi. Jurnal Akuntansi Manajerial, 5(2), 1-11. 